\title{
Ocena wielkości emisji węglowodorów do atmosfery podczas przeładunku i magazynowania oleju napędowego w zbiornikach z dachem stałym
}

\section{Assessment of the amount of hydrocarbon emissions to the atmosphere during handling and storage of diesel fuel in fixed roof tanks}

\author{
Jakub Domin ${ }^{1}$, Marek Piechota ${ }^{1}$, Dymitr Czechowicz², Krzysztof Skutil ${ }^{2}$ \\ ${ }^{1}$ TanQuid Polska Sp. z o.o. \\ ${ }^{2}$ Katedra Technologii Chemicznej Organicznej i Petrochemii, Wydział Chemiczny Politechniki Śląskiej
}

\begin{abstract}
STRESZCZENIE: Oleje napędowe stanowią obecnie około 60-70\% obrotów baz paliw w Polsce. Oleje napędowe magazynowane są w zbiornikach stalowych o osi pionowej z dachami stałymi, niewymagającymi, zgodnie z obowiązującymi przepisami, hermetyzacji. Powoduje to emisję do atmosfery gazów zawierających węglowodory, co przy dużych obrotach baz paliw generuje potrzebę określenia stężenia węglowodorów emitowanych ze zbiornika magazynowego do atmosfery oraz wykonania obliczeń stężeń występujących na granicy działki bazy paliw. W artykule zebrano dostępne dane literaturowe oraz przedstawiono wyniki badań dotyczących emisji węglowodorów do atmosfery, jaka występuje podczas przeładunku i magazynowania oleju napędowego w zbiornikach magazynowych, łącznie z określeniem prężności pary nasyconej węglowodorowych składników badanego oleju napędowego w zależności od temperatury. Badania emisji przeprowadzono poprzez pobranie próbek gazowych emitowanych podczas operacji przeładunkowych i napełniania zbiorników magazynowych oleju napędowego. Analizy próbek gazowych, dostarczonych w strzykawkach gazoszczelnych, wykonywano z użyciem chromatografu SRI 8610C wyposażonego w detektor płomieniowo-jonizacyjny (FID) i w kolumnę pakowaną wypełnioną modyfikowanym tlenkiem glinu. Analizy próbek oleju napędowego mające na celu oznaczenie składu wykonano metodą chromatografii gazowej z wykorzystaniem chromatografu Shimadzu GC-2010 Plus wyposażonego w detektor płomieniowo-jonizacyjny (FID). Do rozdziału substancji zastosowano kolumnę ZB-5HT (30 $\mathrm{m} \times 0,25 \mathrm{~mm} \times 0,25 \mu \mathrm{m})$. W badaniach określono zależność wielkości emisji węglowodorów do atmosfery od rodzaju operacji przeładunkowych, stopnia napełnienia zbiornika magazynowego oraz temperatury oleju. Wyniki badań pokazują zależność stężenia węglowodorów w gazach emitowanych ze zbiornika magazynowego od stopnia napełnienia zbiornika. Wyniki obliczeń prężności par oleju napędowego wykazały zbieżność z większością dostępnych danych literaturowych oraz z wynikami pomiarów. Określono ogólne wytyczne projektowe dotyczące ustalania danych niezbędnych do obliczenia poziomu stężeń węglowodorów w powietrzu atmosferycznym. Przeprowadzone badania miały na celu stworzenie podstawy dla wymaganych obliczeń środowiskowych, istotnych przy niedostatku odpowiednich danych literaturowych, koniecznych do rzetelnego określenia wielkości emisji węglowodorów.
\end{abstract}

Słowa kluczowe: olej napędowy, magazynowanie, emisje węglowodorów, prężność par, współczynniki Antoine’a, wytyczne projektowe.

ABSTRACT: Diesel fuels currently constitute around $60-70 \%$ of the turnover of fuel bases in Poland. Diesel fuels are stored in vertical steel tanks with fixed roofs, which, according to applicable legal acts, do not require airtight sealing. This results in the emission of gases containing hydrocarbons to the atmosphere, which at high turnover of fuel bases generates the need to determine the concentration of hydrocarbons emitted to the atmosphere and to perform calculations of concentrations occurring at the boundary of the fuel base site. The article collects available literature data and presents the results of research on the emissions of hydrocarbons to the atmosphere that occur during handling and storage of diesel fuel in storage tanks, including the determination of the saturated vapor pressure of the hydrocarbon components of the tested diesel fuel depending on the temperature. The emissions tests were carried out by taking gas samples emitted during operations on diesel storage tanks. Analyzes of the gas samples supplied in gas-tight syringes were performed with SRI 8610C gas chromatograph equipped with a flame ionization detector (FID) and an alumina packed column. Diesel oil sample analysis was performed by gas chromatography using Shimadzu GC-2010 Plus chromatograph equipped with flame ionization detector (FID). ZB-5HT column $(30 \mathrm{~m} \times 0.25 \mathrm{~mm} \times 0.25 \mu \mathrm{m})$ was used for the separation of the substances. Research has shown the amount of hydrocarbon emissions to the atmosphere depending on the type of loading operations, the degree of storage tank filling and oil temperature. The dependence of the concentration of hydrocarbons emitted from the storage tank depending on the

Autor do korespondencji: J. Domin, e-mail: jakubdomin@gmail.com

Artykuł nadesłano do Redakcji: 05.11.2019 r. Zatwierdzono do druku: 18.02.2020 r. 
degree of filling of the tank has been determined in the research. Results of calculations of diesel vapor pressure show convergence with most available literature data and measurement results. General design guidelines have been defined to determine the data necessary to calculate the level of hydrocarbon concentrations in atmospheric air. The research was aimed at creating the basis for the required environmental calculations, relevant in the absence of relevant literature data, necessary for the reliable determination of the amount of hydrocarbon emissions.

Key words: Diesel fuel, storage, hydrocarbon emissions, vapor partial pressure, Antoine coefficients, design guidelines.

\section{Wprowadzenie}

Hurtowa sprzedaż paliw ciekłych, głównie olejów napędowych i benzyn silnikowych, prowadzona jest przez bazy magazynowe paliw płynnych, zwane też bazami paliw lub terminalami paliwowymi. Oleje napędowe, obecnie odpowiadające za około $60-70 \%$ obrotów baz paliw, są magazynowane w zbiornikach stalowych o osi pionowej z dachami stałymi o pojemnościach dochodzących do $50000 \mathrm{~m}^{3}$.

Wymagania dotyczące budowy i zabezpieczenia zbiorników do magazynowania oleju napędowego zawiera Rozporządzenie Ministra Gospodarki z dnia 21 listopada 2005 r. w sprawie warunków technicznych, jakim powinny odpowiadać bazy i stacje paliw płynnych, rurociągi przesyłowe dalekosiężne służące do transportu ropy naftowej i produktów naftowych i ich usytuowanie (Dz.U. Nr 243, poz. 2063 z późn. zm.). Zgodnie z tym aktem prawnym zbiorniki do magazynowania oleju napędowego nie wymagają hermetyzacji, a w związku z tym wyposażone są w specjalne „kominki” łączące bezpośrednio przestrzeń gazową zbiornika $\mathrm{z}$ atmosferą.

W czasie napełniania zbiornika olejem napędowym następuje tzw. duży oddech, czyli wypchnięcie ze zbiornika do atmosfery objętości gazów równej objętości produktu, jakim jest napełniony zbiornik. W czasie magazynowania oleju napędowego w zbiorniku, bez jego poboru ze zbiornika i bez napełniania zbiornika, występują tzw. małe oddechy, czyli emisja niewielkich ilości gazów wskutek zmian temperatury spowodowanych warunkami pogodowymi.

Dopuszczalne uśrednione stężenie węglowodorów w gazach odprowadzanych ze zbiornika do atmosfery, zwanych także gazami zrzutowymi, jest podane w przywołanym powyżej rozporządzeniu Ministra Gospodarki dotyczącym baz paliw płynnych i wynosi maksymalnie $35 \mathrm{~g} / \mathrm{m}^{3}$ na godzinę, określone zgodnie z podaną $\mathrm{w}$ rozporządzeniu metodyką pomiaru. Gazy wypychane ze zbiorników magazynowych oleju napędowego ze względu na niską prężność par (odpowiadającą stężeniu węglowodorów znacznie poniżej $35 \mathrm{~g} / \mathrm{m}^{3}$ ) zawierają znacznie mniej węglowodorów od dopuszczalnej granicy stężenia.

W przypadku dużej liczby operacji przeładunkowych olejów napędowych w bazach paliw o wysokich obrotach (powyżej $1 \mathrm{mln}$ ton/rok), a zwłaszcza przy jednoczesnym zlokalizowaniu zbiorników magazynowych oleju napędowego w niewielkiej odległości od granicy bazy paliw, wymuszona staje się potrzeba wykonania dodatkowych obliczeń poziomu stężeń węglowodorów w powietrzu atmosferycznym. W takim przypadku, zgodnie z metodyką podaną w Rozporządzeniu Ministra Środowiska z dnia 26 stycznia 2010 r. w sprawie wartości odniesienia dla stężeń niektórych substancji w powietrzu, niezbędne jest wykonanie obliczeń stężeń występujących na granicy działki bazy paliw. Prawidłowa metodologia tych obliczeń wymaga właściwych danych wejściowych, określonych zgodnie z wyżej cytowanym rozporządzeniem, głównie w zakresie rzeczywistych emisji par oleju napędowego znajdujących się w gazach odprowadzanych ze zbiornika do atmosfery w trakcie „dużego i małego oddechu”.

Wartości odniesienia, wyrażone w mikrogramach na metr sześcienny $\left[\mu \mathrm{g} / \mathrm{m}^{3}\right]$, dla węglowodorów alifatycznych do $C_{12}$ występujących w parach oleju napędowego wynoszą: uśrednione dla okresu 1 godziny - 3000, a uśrednione dla okresu jednego roku kalendarzowego - 1000 .

Obecnie istnieje bardzo niewiele informacji literaturowych przydatnych do rzetelnego określenia wielkości takiej emisji.

Celem niniejszej publikacji jest przedstawienie i porównanie dostępnych danych, zaprezentowanie wyników własnych obliczeń oraz rezultatów oznaczeń zawartości węglowodorów w gazach zrzutowych ze zbiorników z olejem napędowym do atmosfery. Oznaczenia te, wykonane przez TanQuid Polska Sp. z o.o. we współpracy z Politechniką Śląską w Gliwicach, dotyczyły zagadnień związanych z emisją do atmosfery węglowodorów, jaka występuje podczas magazynowania oleju napędowego w zbiornikach stalowych o osi pionowej.

Przeprowadzony przegląd literatury, obliczenia oraz oznaczenia pozwoliły na określenie w niniejszej publikacji:

- sumarycznej prężności pary nasyconej węglowodorowych składników oleju napędowego w zależności od temperatury;

- emisji węglowodorów do atmosfery podczas napełniania zbiornika („duży oddech”);

- emisji węglowodorów do atmosfery w czasie magazynowania (,mały oddech”);

- ogólnych wytycznych projektowych dla ustalenia danych koniecznych do obliczenia poziomu stężeń węglowodorów w powietrzu atmosferycznym. 


\section{Dane literaturowe - analiza stanu wiedzy}

\section{Wybrane właściwości oleju napędowego}

Niżej podano typowe właściwości olejów napędowych wg normy PN-EN 590+A1 oraz według kart charakterystyki różnych firm. Drukiem pogrubionym podano dane pochodzące od głównych udziałowców na polskim rynku (Lotos, 2018; Slovnaft, 2018; Total, 2018), w nawiasach zaprezentowano dane pochodzące z innych źródeł (Apex Oil Company, 2015; Vitol, 2015; Chevron Philips, 2017; CITGO, 2018; Naftan, 2018; Shell, 2018).

a) Gęstość w $15^{\circ} \mathrm{C}\left[\mathrm{kg} / \mathrm{m}^{3}\right]$ :

800-845

$(800-876)$

b) Gęstość par względem powietrza:

\section{5-6}

$(>5)$

c) Początkowa temperatura wrzenia $\left[{ }^{\circ} \mathrm{C}\right]$ : 170-180

d) Temperatura zapłonu $\left[{ }^{\circ} \mathrm{C}\right]$ :

$>55$ (wymagana)

e) Granice wybuchowości [\% obj.]: dolna (DGW): $\mathbf{0 , 5}$

$1,3(\mathrm{LOTOS})$ górna (GGW): 5-6,5

f) Średnia masa molowa par oleju $[\mathrm{kg} / \mathrm{kmol}]$ : $>\mathbf{1 4 0}$ (obliczona na podstawie podanej w punkcie b gęstości par względem powietrza)

\section{Regulacje prawne dotyczace dopuszczalnej emisji} węglowodorów do atmosfery

a) Rozporządzenie Ministra Gospodarki z dnia 21 listopada 2005 r. w sprawie warunków technicznych, jakim powinny odpowiadać bazy i stacje paliw płynnych, rurociagi przesyłowe dalekosiężne służące do transportu ropy naftowej i produktów naftowych i ich usytuowanie.

Wartość dopuszczalna według rozporządzenia: $35 \mathrm{~g} / \mathrm{m}^{3}$ w ciągu godziny ( $§ 11$, pkt 3$)$.

Tabela 1. Prężności par i stężenia sumaryczne węglowodorów (olejów) w różnych warunkach

Table 1. Vapor pressures and total concentrations of hydrocarbons (oils) under various conditions

\begin{tabular}{|c|c|c|c|c|}
\hline \multirow{2}{*}{ Lp. } & \multirow{2}{*}{ Nazwa dokumentu } & Prężność par olejów & Stężenie węglowodorów & \multirow{2}{*}{ Warunki } \\
\hline & & {$[\mathrm{kPa}]$} & {$\left[\mathrm{g} / \mathbf{m}^{3}\right]^{*}$} & \\
\hline \multirow{7}{*}{1.} & \multirow{7}{*}{$\begin{array}{l}\text { USA's Environmental Protection Agency } \\
\text { publication AP-42 - Compilation of Air } \\
\text { Pollutant Emissions, rozdział } 7 \text { (EPA) }\end{array}$} & 0,0214 & 1,24 & $\mathrm{w} 4,44^{\circ} \mathrm{C}$ \\
\hline & & 0,0310 & 1,80 & w $10^{\circ} \mathrm{C}$ \\
\hline & & 0,0448 & 2,60 & w $15,55^{\circ} \mathrm{C}$ \\
\hline & & 0,0620 & 3,60 & w $21,11^{\circ} \mathrm{C}$ \\
\hline & & 0,0827 & 4,80 & w $26,67^{\circ} \mathrm{C}$ \\
\hline & & 0,1103 & 6,40 & w $32,22^{\circ} \mathrm{C}$ \\
\hline & & 0,1517 & 8,80 & w $37,78^{\circ} \mathrm{C}$ \\
\hline 2. & $\begin{array}{l}\text { Karta charakterystyki } \\
\text { (Apex Oil Company, 2015) }\end{array}$ & 0,1333 & 7,74 & w $20^{\circ} \mathrm{C}$ \\
\hline 3. & $\begin{array}{l}\text { Karta charakterystyki } \\
\text { (Chevron Philips, 2017) }\end{array}$ & 0,10 & 5,80 & w $40^{\circ} \mathrm{C}$ \\
\hline 4. & $\begin{array}{l}\text { Karta charakterystyki } \\
\text { (Shell, 2018) }\end{array}$ & 0,4 & 23,21 & w $0^{\circ} \mathrm{C}$ \\
\hline 5. & $\begin{array}{l}\text { Karta charakterystyki } \\
\text { (Naftan, 2018) }\end{array}$ & 0,4 & 23,21 & w $20^{\circ} \mathrm{C}$ \\
\hline 6. & $\begin{array}{l}\text { Karta charakterystyki } \\
\text { (Lotos, 2018) }\end{array}$ & 0,4 & 23,21 & w $40^{\circ} \mathrm{C}$ \\
\hline 7. & $\begin{array}{l}\text { Karta charakterystyki } \\
\text { (Slovnaft, 2018) }\end{array}$ & 0,4 & 23,21 & $\mathrm{w} 40^{\circ} \mathrm{C}$ \\
\hline 8. & $\begin{array}{l}\text { Karta charakterystyki } \\
\text { (Total, 2018) }\end{array}$ & $<1$ & 58,04 & w $37,8^{\circ} \mathrm{C}$ \\
\hline 9. & $\begin{array}{l}\text { Karta charakterystyki } \\
\text { (CITGO, 2018) }\end{array}$ & 0,27 & 15,67 & temperatura otoczenia \\
\hline 10. & $\begin{array}{l}\text { Karta charakterystyki } \\
\text { (Vitol, 2015) }\end{array}$ & $0,28-0,35$ & $16,25-20,31$ & w $21^{\circ} \mathrm{C}$ \\
\hline 11. & Obliczenie na podstawie $\mathrm{DGW}^{* *}$ & 0,5 & 31,25 & w $55^{\circ} \mathrm{C}$ \\
\hline
\end{tabular}

* Obliczenia dla pozycji 1-11 dla średniej masy molowej $130 \mathrm{~kg} / \mathrm{kmol}$.

** DGW - dolna granica wybuchowości - obliczenia wykonano dla DGW równej 0,5\% obj. przy przyjęciu średniej masy molowej wynoszącej 130 kg/kmol. 
b) Rozporządzenie Ministra Środowiska z dnia 26 stycznia 2010 r. w sprawie wartości odniesienia dla stężenia niektórych substancji w powietrzu.

Wartość odniesienia według rozporządzenia:

- uśredniona dla okresu 1 godziny: $3000 \mu \mathrm{g} / \mathrm{m}^{3}$;

- uśredniona dla okresu roku kalendarzowego: $1000 \mu \mathrm{g} / \mathrm{m}^{3}$

- (wartości uśrednione dla węglowodorów alifatycznych do $\mathrm{C}_{12}$, załącznik 1 rozporządzenia, poz. 164).

\section{Prężność par oleju napędowego}

Prężność par nasyconych składników oleju napędowego dla różnych temperatur zależy od składu oleju i może się znacznie różnić między poszczególnymi typami olejów napędowych. W tabeli 1 przedstawiono wartości sumarycznej prężności par olejów typu 2 (Diesel Fuel Oil No. 2) opublikowane w różnych dostępnych materiałach źródłowych, głównie w kartach charakterystyk firm zajmujących się produkcją i dystrybucją oleju oraz w publikacji AP-42 (EPA).

\section{Metody szacowania wielkości emisji}

Niniejszy artykuł odnosi się do znanych z literatury metod obliczania wielkości emisji i korzysta z dostępnych źródeł danych:

a) metoda szacowania emisji gazów na podstawie danych przedstawionych w publikacji Oczyszczanie gazów odlotowych wydawnictwa Politechniki Śląskiej (Konieczyński, 1993) - dane dotyczące źródeł emisji węglowodorów w czasie transportu i dystrybucji paliw płynnych, jak i magazynowania paliw w zbiornikach $\mathrm{z}$ dachem stałym $\mathrm{i}$ dachem pływającym w czasie „dużego i małego oddechu”;

b) metoda obliczeniowa emisji gazów ze zbiorników magazynowych ciekłych związków organicznych według opracowania AP-42 (EPA), rozdział 7 - rozdział dotyczący między innymi określenia emisji gazów ze zbiorników różnego typu, w tym ze zbiorników $\mathrm{z}$ dachami stałymi i dachami pływającymi;

c) metoda obliczania emisji z równania stanu gazu doskonałego oraz prawa Raoulta przy wykorzystaniu danych temperaturowych uzyskanych z własnych pomiarów.

\section{Prężności par oleju napędowego}

\section{Analiza sktadu oleju napędowego}

W tabeli 2 przedstawiono skład dostarczonej przez TanQuid Polska Sp. z o.o. próbki oleju napędowego pobranej ze zbiornika magazynowego, w którym magazynowana była mieszanina oleju napędowego pochodząca od różnych dostawców. Oznaczenie wykonano metodą chromatografii gazowej z wykorzystaniem chromatografu Shimadzu GC-2010 Plus.
Tabela 2. Skład grupowy próbki oleju napędowego

Table 2. Group composition of diesel fuel sample

\begin{tabular}{|c|c|c|}
\hline \multirow{2}{*}{$\begin{array}{c}\text { Grupa } \\
\text { węglowodorów }\end{array}$} & Udzial masowy & Udział molowy \\
\hline & {$[\%]$} & {$[\%]$} \\
\hline $\mathrm{C}_{7}$ & 0,3 & 0,6 \\
\hline $\mathrm{C}_{8}$ & 0,7 & 1,3 \\
\hline $\mathrm{C}_{9}$ & 2,9 & 4,7 \\
\hline $\mathrm{C}_{10}$ & 5,3 & 7,8 \\
\hline $\mathrm{C}_{11}$ & 6,1 & 8,3 \\
\hline $\mathrm{C}_{12}$ & 7,2 & 8,9 \\
\hline $\mathrm{C}_{13}$ & 8,1 & 9,3 \\
\hline $\mathrm{C}_{14}$ & 9,0 & 9,5 \\
\hline $\mathrm{C}_{15}$ & 9,3 & 9,2 \\
\hline $\mathrm{C}_{16}$ & 8,7 & 8,1 \\
\hline $\mathrm{C}_{17}$ & 8,2 & 7,2 \\
\hline $\mathrm{C}_{18}$ & 7,2 & 6,0 \\
\hline $\mathrm{C}_{19}$ & 6,6 & 5,2 \\
\hline $\mathrm{C}_{20}$ & 5,1 & 3,8 \\
\hline $\mathrm{C}_{21}$ & 4,4 & 3,1 \\
\hline $\mathrm{C}_{22}$ & 3,2 & 2,2 \\
\hline $\mathrm{C}_{23}$ & 2,7 & 1,7 \\
\hline $\mathrm{C}_{24}$ & 2,1 & 1,3 \\
\hline $\mathrm{C}_{25}$ & 1,4 & 0,8 \\
\hline $\mathrm{C}_{26}$ & 0,8 & 0,5 \\
\hline $\mathrm{C}_{27}$ & 0,4 & 0,2 \\
\hline $\mathrm{C}_{28+}$ & 0,3 & 0,2 \\
\hline
\end{tabular}

Do rozdziału substancji zastosowano kolumnę ZB-5HT (30 $\mathrm{m} \times 0,25 \mathrm{~mm} \times 0,25 \mu \mathrm{m})$.

Średnia masa molowa wyliczona na podstawie przedstawionego składu wynosi $211 \mathrm{~g} / \mathrm{mol}$.

\section{Wyznaczenie krzywej prężności par w zależności od temperatury}

Na podstawie składu grupowego badanej próbki, wykorzystując dostępne w literaturze (Yaws et al., 2009) wartości współczynników równania Antoine’a:

$$
\log _{10} P=A-\frac{B}{C+T}
$$

gdzie:

$P$ - prężność pary nasyconej [mmHg],

$T$ - temperatura $\left[{ }^{\circ} \mathrm{C}\right]$,

$A, B, C$-współczynniki,

można oszacować prężności par badanego oleju napędowego w funkcji temperatury. Dla przedziału od $-20^{\circ} \mathrm{C}$ do $+40^{\circ} \mathrm{C}$ tę (przybliżoną) zależność przedstawiono na rysunku 1. 


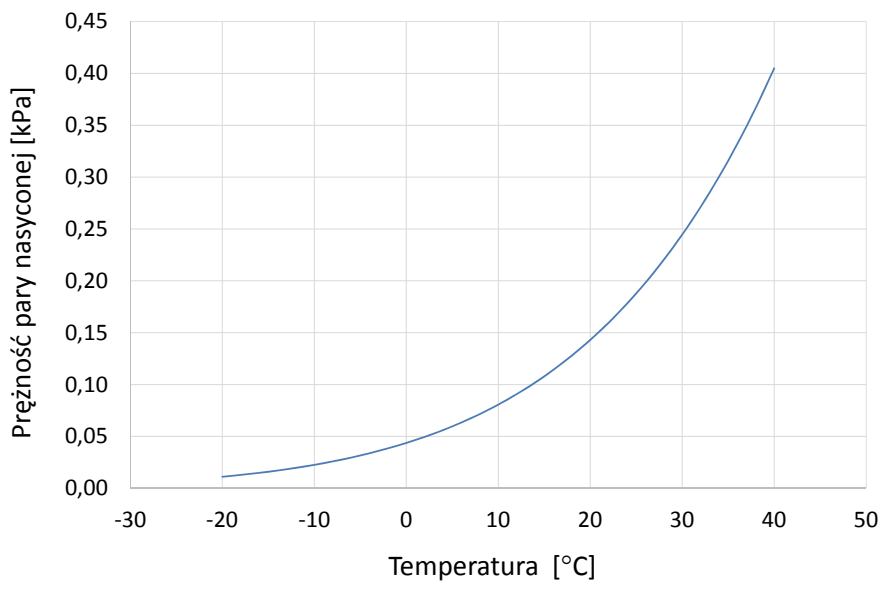

Rys. 1. Przybliżona zależność prężności pary nasyconej badanej próbki oleju napędowego od temperatury

Fig. 1. Approximate dependence of saturated vapor pressure of tested diesel fuel sample on temperature

Przebieg zaprezentowanej zależności można przybliżyć równaniem o postaci analogicznej do równania Antoine'a przy następujących wartościach współczynników: $A=7,332$; $B=2215,5$ i $C=283,432$.

\section{Porównanie wyników obliczeń prężności par} z wyznaczonych wspótczynników Antoine'a z wynikami analiz prężności par uzyskanymi w czasie badań wlasnych TanQuid

Równanie Antoine'a przy wykorzystaniu podanych wyżej współczynników dla oleju napędowego pozwala na otrzymanie przybliżonych wartości prężności pary nasyconej dla różnych wartości temperatury. W celu sprawdzenia poprawności podanej zależności porównano wyniki obliczeń z wynikami badań własnych TanQuid Polska (TanQuid, 2019) dotyczących analizy laboratoryjnej składu i stężenia fazy gazowej znad próbek oleju w warunkach termostatowanych dla temperatur: $-10^{\circ} \mathrm{C}, 0^{\circ} \mathrm{C} \mathrm{i}+30^{\circ} \mathrm{C}$.

W tabeli 3 zestawiono obliczone na podstawie równania Antoine'a prężności par oleju napędowego dla temperatur: $-10^{\circ} \mathrm{C}, 0^{\circ} \mathrm{C} \mathrm{i}+30^{\circ} \mathrm{C}$ (bez uwzględnienia nieobjętych analizą składu obecnych w oleju w niewielkich ilościach alkanów $\mathrm{C}_{3}-\mathrm{C}_{6}$ ) i odpowiadające tym prężnościom udziały węglowodorów w powietrzu (przy ciśnieniu $101,325 \mathrm{kPa}$ ) oraz udziały węglowodorów uzyskane w badaniach laboratoryjnych.

Otrzymane wartości nie są identyczne, niemniej uzyskane przybliżenie można dla tego typu technicznych zagadnień uznać za wystarczające $\mathrm{w}$ przedziale temperatur od $0^{\circ} \mathrm{C}$ do $+30^{\circ} \mathrm{C}$.

\section{Obliczenia wielkości emisji węglowodorów do atmosfery}

Obliczenia emisji wykonane zostały dla zbiorników stalowych z dachem stałym o następującej charakterystyce:

- pojemność całkowita: $V_{L X}=9970 \mathrm{~m}^{3}$;

- pojemność robocza: $V_{R}=9400 \mathrm{~m}^{3}$;

- średnica zbiornika: $D=29 \mathrm{~m}$;

- średnica ściany osłonowej: $D_{s c}=33 \mathrm{~m}$;

- promień części cylindrycznej: $R_{S}=14,5 \mathrm{~m}$;

- wysokość płaszcza zbiornika: $H_{S}=15 \mathrm{~m}$;

- wysokość całkowita: $H_{T}=17,9 \mathrm{~m}$;

- wysokość ściany osłonowej: $H_{C}=12 \mathrm{~m}$;

- promień dachu: $R=37,7 \mathrm{~m}$;

- wysokość dachu: $H_{R}=2,9 \mathrm{~m}$;

- maksymalna wysokość paliwa w zbiorniku $H_{L X}=14 \mathrm{~m}$.

\section{Obliczenia emisji gazów na podstawie danych} przedstawionych w publikacji J. Konieczyńskiego (1993)

Według wskazanej publikacji metoda szacowania emisji gazów dla zbiorników z dachem stałym odnosi się zarówno do emisji związanej z termicznym oddechem zbiornika (,mały oddech"), jak też do operacji eksploatacji zbiornika (napełnianie, opróżnianie - „duży oddech”). Publikacja podaje dla „małego oddechu” wartość równą $0,043 \mathrm{~kg} / \mathrm{dobę} / \mathrm{m}^{3}$ pojemności magazynowej zbiornika oraz dla „dużego oddechu” wartość $0,12 \mathrm{~kg} / \mathrm{m}^{3}$ przepustowości zbiornika. Wartości te dotyczą nafty i oleju naftowego.

W opinii autorów niniejszego artykułu nie ma uzasadnienia stosowanie metody szacowania emisji węglowodorów do atmosfery ze zbiorników magazynowych oleju napędowego na podstawie danych zamieszczonych w przedmiotowej publikacji, przytoczonych powyżej, z następujących powodów:

a) w publikacji nie podano danych jednoznacznie dotyczących oleju napędowego;

b) podane dane emisji dla nafty, jak i oleju naftowego są identyczne i dotyczą frakcji znacznie lżejszych (o większej prężności par) od oleju napędowego;

Tabela 3. Porównanie zawartości sumy składników węglowodorów obliczonych i wyznaczonych doświadczalnie

Table 3. Comparison of the calculated and experimentally determined content of the sum of hydrocarbon components

\begin{tabular}{|c|c|c|c|}
\hline Temperatura & Prężność par & $\begin{array}{c}\text { Suma węglowodorów } \\
\text { uzyskana z obliczonej } \\
\text { prężności par }\end{array}$ & $\begin{array}{c}\text { Suma węglowodorów } \\
\text { uzyskana z badań labora- } \\
\text { toryjnych }\end{array}$ \\
\hline$\left[{ }^{\circ} \mathbf{C}\right]$ & {$[\mathbf{k P a}]$} & {$[\%$ obj. $]$} & {$[\%$ obj. $]$} \\
\hline \hline-10 & 0,0226 & 0,022 & 0,036 \\
\hline 0 & 0,0437 & 0,043 & 0,045 \\
\hline+30 & 0,2447 & 0,241 & 0,178 \\
\hline
\end{tabular}


c) wielkość emisji w czasie ,pracy” (przy napełnianiu zbiornika) wg publikacji wynosi $120 \mathrm{~g} / \mathrm{m}^{3}$, a więc jest wielokrotnie wyższa od emisji mogącej wystąpić podczas napełniania zbiornika olejem napędowym, wynoszącej 5,09 g/m³ dla średniej rocznej temperatury $10^{\circ} \mathrm{C}$;

d) wielkość emisji wg publikacji w czasie ,małego oddechu” nie jest związana z konstrukcją zbiornika, nie ma też związku ze stopniem napełnienia zbiornika;

e) wielkość emisji w czasie „małego oddechu” odniesiona jest do jednej doby bez określenia warunków atmosferycznych, a więc odnoszenie jej do roku może być obarczone bardzo dużym błędem.

\section{Metoda obliczeniowa emisji gazów ze zbiorników magazynowych ciektych związków organicznych wedlug opracowania AP-42: Compilation of Air Emissions \\ Factors (EPA)}

Obliczenia według AP-42 (EPA) wykonano na podstawie algorytmu obliczeniowego zamieszczonego w rozdziale 7 przywołanej publikacji. Algorytm ten umożliwia obliczenie wyłącznie strat rocznych magazynowanego produktu powstałych zarówno wskutek zmian temperaturowych (,mały oddech”), jak i operacji przeładunkowych (,duży oddech”).

A. Obliczenia zostały wykonane dla trzech wariantów wypełnienia zbiornika:

- zbiornik pełny - wypełnienie zbiornika do 13 m wysokości;

- zbiornik średnio wypełniony - wypełnienie zbiornika do 8 m wysokości;

- zbiornik pusty - wypełnienie zbiornika do $3 \mathrm{~m}$ wysokości.

B. Do obliczeń przyjęto następujące dane:

- średnia roczna temperatura produktu:

$T_{L A}=10,0^{\circ} \mathrm{C}\left({ }^{1}\right)$;

- prężność par magazynowanego produktu:

$P_{V A}=0,0310 \mathrm{kPa}\left(1,80 \mathrm{~g} / \mathrm{m}^{3}\right)\left({ }^{2}\right)$;

- masa molowa magazynowanego produktu: $M_{V}=130 \mathrm{~kg} / \mathrm{kmol}$ (jak w tabeli 1).

C. Do obliczeń strat związanych z operacjami przeładunkowymi przyjęto roczną przepustowość zbiornika wynoszącą: $Q=100000 \mathrm{~m}^{3} /$ rok

W tabeli 4 przedstawiono wyniki obliczeń wykonanych dla podanych danych i założeń.

\footnotetext{
${ }^{1}$ Temperatura przyjęta na podstawie danych historycznych wartości temperatur produktu w zbiornikach w bazie paliw TanQuid.

${ }^{2}$ Dane zgodne z tabelą 1 , punkt 1 .
}

Tabela 4. Straty związane z magazynowaniem i operacjami przeładunkowymi

Table 4. Losses related to storage and handling operations

\begin{tabular}{|l|c|c|c|}
\hline \multicolumn{1}{|c|}{ Rodzaj strat } & $\begin{array}{c}\text { Pusty } \\
\text { zboiornik }\end{array}$ & $\begin{array}{c}\text { Częściowo } \\
\text { napelniony } \\
\text { zbiornik }\end{array}$ & $\begin{array}{c}\text { Pełny } \\
\text { zbiornik }\end{array}$ \\
\hline \hline $\begin{array}{l}\text { Roczne straty wynikające } \\
\text { z magazynowania produktu } L_{S}\end{array}$ & 93,52 & 59,03 & 24,28 \\
\hline $\begin{array}{l}\text { Roczne straty wynikające } \\
\text { z operacji przeładunkowych } L_{W}\end{array}$ & 153,24 & 153,24 & 153,24 \\
\hline $\begin{array}{l}\text { Całkowite roczne straty pro- } \\
\text { duktu } L_{S}+L_{W}=L_{T}\end{array}$ & 246,76 & 212,27 & 177,51 \\
\hline
\end{tabular}

Podsumowanie obliczeń:

Stężenie węglowodorów odpowiadające prężności pary nasyconej: $1,80 \mathrm{~g} / \mathrm{m}^{3}$

Średnie stężenie węglowodorów w gazach (,duży oddech"): $1,53 \mathrm{~g} / \mathrm{m}^{3}$

Średni stopień nasycenia: 0,85

Straty roczne („duży oddech”) - niezależnie od napełnienia: $153,24 \mathrm{~kg} / \mathrm{rok}$

Średnia ilość gazów odprowadzanych do atmosfery w ciągu doby: $100000 / 365=274 \mathrm{~m}^{3} /$ dobę

Straty roczne („,mały oddech”) - pusty zbiornik: $93,52 \mathrm{~kg} / \mathrm{rok}$ Średnia prężność par w gazach (,mały oddech”): $1,53 \mathrm{~g} / \mathrm{m}^{3}$ Średni zrzut dobowy gazów: 93 520/(1,53 × 365) $=167 \mathrm{~m}^{3} /$ dobę

Straty roczne („mały oddech”) - częściowo napełniony zbiornik: $9,03 \mathrm{~kg} / \mathrm{rok}$

Średnia prężność par w gazach (,mały oddech”): $1,53 \mathrm{~g} / \mathrm{m}^{3}$ Średni zrzut dobowy gazów: $59030 /(1,53 \times 365)=106 \mathrm{~m}^{3} /$ dobę

Straty roczne („mały oddech”) - pełny zbiornik: $24,28 \mathrm{~kg} / \mathrm{rok}$ Średnia prężność par w gazach (,mały oddech”): $1,53 \mathrm{~g} / \mathrm{m}^{3}$ Średni zrzut dobowy gazów: $24280 /(1,53 \times 365)=43 \mathrm{~m}^{3} /$ dobę

„Duży oddech” następuje tylko z aktualnie napełnianego zbiornika, zaś „mały oddech” występuje równocześnie ze wszystkich zbiorników magazynowych znajdujących się na terenie danej bazy magazynowej.

Wyższe straty przy pustym zbiorniku wynikają z większej przestrzeni gazowej zbiornika branej pod uwagę $\mathrm{w}$ algorytmie obliczeń według AP-42.

\section{Metoda obliczania emisji na podstawie równania stanu gazu doskonatego i pomiarów własnych}

\section{Źródła przyjętych danych:}

- prężności pary nasyconej oleju napędowego obliczono na podstawie równania Antoine’a przy współczynnikach 
podanych we wcześniejszym rozdziale niniejszego opracowania;

- dane dla warunków ekstremalnych (lipiec, pełne nasłonecznienie, maksymalna temperatura produktu, maksymalna dobowa różnica temperatury) zostały określone na podstawie pomiarów wykonanych w bazie paliw TanQuid Polska (TanQuid, 2019);

- dane średnie roczne oszacowano na podstawie danych meteorologicznych dla rejonu Radzionkowa;

- stopień nasycenia gazów zrzutowych oszacowano na podstawie wykonanych badań własnych we współpracy z Politechniką Śląską (TanQuid, 2019).

\section{Dane przyjęte do obliczeń:}

- przestrzeń gazowa:

- pełny zbiornik: $1640 \mathrm{~m}^{3}$,

- średni zbiornik: $4600 \mathrm{~m}^{3}$,

- pusty zbiornik: $8000 \mathrm{~m}^{3}$;

- prężność pary nasyconej:

- w $28^{\circ} \mathrm{C}: 0,225 \mathrm{kPa}\left(13,90 \mathrm{~g} / \mathrm{m}^{3}\right)$,

- w $10^{\circ} \mathrm{C}: 0,083 \mathrm{kPa}\left(5,09 \mathrm{~g} / \mathrm{m}^{3}\right)$;

- stopień nasycenia (dla emisji maksymalnych):

- pełny zbiornik: 0,75

- średni zbiornik: 0,3

- pusty zbiornik: 0,1 ;

- $\quad$ stopień nasycenia (dla emisji rocznych):

- pełny zbiornik: 0,4

- średni zbiornik: 0,3

- pusty zbiornik: 0,1;

- temperatura produktu:

- maksymalna w ciągu doby: $28^{\circ} \mathrm{C}\left({ }^{3}\right)$,

- średnia roczna: $10^{\circ} \mathrm{C}\left({ }^{3}\right)$;

- przyrost temperatury powierzchni produktu w czasie doby: $2^{\circ} \mathrm{C}\left({ }^{3}\right)$;

- przyrost temperatury produktu w czasie 1 godziny: do pominięcia;

- temperatura przestrzeni gazowej (minimalna w ciągu doby): $18^{\circ} \mathrm{C}$;

- maksymalny dobowy przyrost temperatury przestrzeni gazowej: $18^{\circ} \mathrm{C}$;

- $\quad$ przyrost prężności par dla $d T=1{ }^{\circ} \mathrm{C}$ (T produktu): $0,004 \mathrm{kPa}(0,004 \%$ obj. $)\left({ }^{3}\right)$;

- czas trwania „małego oddechu” (przyrostu temperatury): do 10 godz./dobę $\left.{ }^{3}\right)$;

- maksymalny przyrost temperatury gazu: $2,5^{\circ} \mathrm{C} / \operatorname{godz} .\left(^{3}\right)$;

- liczba dni w roku, w których występuje znaczący ,mały oddech": 175 dni $/ \operatorname{rok}\left({ }^{4}\right)$;

${ }^{3}$ Dane pochodzą z badań własnych (Tanquid, 2019).

${ }^{4}$ Dane meteorologiczne (Klimat Radzionków, 2019).
- średni dobowy przyrost temperatury w zbiorniku: $70 \%$ maksymalnego.

Przyrost objętości gazów w czasie ,, małego oddechu”

$w$ warunkach ekstremalnych

W ciągu doby:

- pełny zbiornik:

$1640 \times(309 / 291+0,0001)-1640=102 \mathrm{~m}^{3} /$ dobę;

- średni zbiornik: $4600 \times(309 / 291+0,0001)-4600=285 \mathrm{~m}^{3} /$ dobę;

- pusty zbiornik: $8000 \times(309 / 291+0,0001)-8000=495 \mathrm{~m}^{3} /$ dobę.

W ciągu godziny:

- pełny zbiornik: $1640 \times(293,5 / 291)-1640=14 \mathrm{~m}^{3} /$ godz.;

- średni zbiornik: $4600 \times(293,5 / 291)-4600=40 \mathrm{~m}^{3} / \mathrm{godz}$;

- pusty zbiornik: $8000 \times(293,5 / 291)-8000=69 \mathrm{~m}^{3} /$ godz .

Przyrost objętości gazów obliczono, uwzględniając maksymalny dobowy przyrost temperatury przy wykorzystaniu równań opisujących stan gazu doskonałego.

\section{Straty zwiazane z magazynowaniem (emisja)}

W ciągu godziny (maksymalnie):

- pełny zbiornik: $14 \times 13,90 \times 0,75=\mathbf{1 4 6}$ g/godz.;

- średni zbiornik: $40 \times 13,90 \times 0,3=\mathbf{1 6 7} \mathbf{g} / \mathbf{g o d z}$;

- pusty zbiornik: $69 \times 13,90 \times 0,1=96 \mathbf{g} / \mathbf{g o d z}$.

W ciągu roku:

- pełny zbiornik: $(175 \times 102 \times 5,09 \times 0,4 \times 0,7) / 1000=\mathbf{2 5} \mathbf{~ k g} / \mathbf{r o k} ;$

- średni zbiornik: $(175 \times 285 \times 5,09 \times 0,3 \times 0,7) / 1000=\mathbf{5 3} \mathbf{~ k g} / \mathbf{r o k} ;$

- pusty zbiornik:

$(175 \times 495 \times 5,09 \times 0,1 \times 0,7) / 1000=\mathbf{3 1} \mathbf{~ k g} / \mathbf{r o k}$.

\section{Obliczanie , dużego oddechu”}

Emisja (straty) z „dużego oddechu” zbiornika operacyjnego wynika $\mathrm{z}$ intensywności napełniania zbiornika (emisja maksymalna w ciągu godziny) lub całkowitej rocznej przepustowości zbiornika (emisja roczna).

Dane do obliczeń są identyczne jak wyżej dla „małego oddechu".

Dodatkowe dane:

- maksymalna intensywność zasilania: $900 \mathrm{~m}^{3} /$ godz.;

- stopień nasycenia:

- dla emisji maksymalnej godzinowej: 0,75

- dla emisji rocznej: 0,4 .

Straty wynikające $\mathrm{z}$ napełniania zbiornika:

- w ciągu godziny (maksymalnie): $900 \times 13,9 \times 0,75=9383 \mathrm{~g} / \mathrm{godz}$;

- w ciągu roku: $100000 \times 5,09 \times 0,4=203,6 \mathrm{~kg} / \mathrm{rok}$. 
Porównanie wielkości strat związanych z magazynowaniem

Obliczenie emisji (strat) rocznych dla danych i parametrów przyjętych do obliczeń według AP-42 (EPA) dają podobne wyniki jak wyniki uzyskane z obliczeń według prawa stanu gazu doskonałego dla „małego oddechu” przy maksymalnym i średnim napełnieniu zbiornika. W przypadku „dużego oddechu” różnica sięga 33\%. Przy pustym zbiorniku otrzymywane wyniki znacznie się różnią, co nie ma istotnego znaczenia, ponieważ w praktyce zbiorniki dla rezerw wypełnione są w $100 \%$, a zbiorniki operacyjne średnio w 60\%.

\section{Badania emisji węglowodorów do atmosfery}

Badania emisji (zrzutów) węglowodorów zostały wykonane na próbkach gazowych pobranych podczas przeładunku i magazynowania oleju napędowego w zbiornikach z dachem stałym na terenie bazy paliw TanQuid Polska Sp. z o.o. w Radzionkowie. Badania były podzielone na dwie części: badania wielkości emisji do atmosfery w trakcie tzw. dużego oddechu oraz tzw. małego oddechu. Badania zostały przeprowadzone dla zbiorników o różnym stopniu wypełnienia zgodnie $\mathrm{z}$ opisem w punktach poniżej.

Próbki gazowe zostały pobrane znad zaworów oddechowych oraz kominków zbiorników w sposób bezpośredni przy użyciu strzykawek gazoszczelnych. Analizy próbek gazowych dostarczonych w strzykawkach gazoszczelnych wykonano na chromatografie SRI 8610C wyposażonym w detektor płomieniowo-jonizacyjny (FID) i w kolumnę pakowaną wypełnioną modyfikowanym tlenkiem glinu.

$\mathrm{W}$ trakcie poboru i analiz stosowano procedury zawarte w:

- EN ISO/IEC 17025 Ogólne wymagania dotyczace kompetencji laboratoriów badawczych i wzorcujacych;

- PN-EN 13649:2005 Emisja ze źródet stacjonarnychOznaczanie stężenia masowego indywidualnych gazowych związków organicznych - Metoda z zastosowaniem węgla aktywnego i desorpcji rozpuszczalnikiem.

\section{Analiza próbek gazowych tzw. dużego oddechu}

Próbki gazowe z tzw. dużego oddechu zostały pobrane ze zbiorników magazynowych o numerach 10.5 i 10.3, o różnym stopniu wypełnienia paliwem ciekłym, w których znajdowała się mieszanina olejów napędowych pochodzących od różnych dostawców. W przypadku każdego zbiornika pobrano po pięć próbek gazowych w przedziale czasowym co 2 minuty. Poniżej zamieszczono dane zbiorników magazynowych, w tym warunki poboru próbek gazowych.

Za zbiornik, „pełny” uważano zbiornik, który w trakcie operacji przeładunkowych został wypełniony paliwem do maksymalnego możliwego stopnia wypełnienia:
- numer zbiornika: 10.5;

- $V=10000 \mathrm{~m}^{3}$;

- $\quad$ średnica zbiornika: $29 \mathrm{~m}$;

- maksymalna wysokość paliwa w zbiorniku: 14 m;

- wysokość zbiornika do króćca pomiarowego: 15 m;

- napełnianie od około $8600 \mathrm{~m}^{3}$ (około $13 \mathrm{~m}$ ) do około $9200 \mathrm{~m}^{3}$ (około $14 \mathrm{~m}$ );

- Średnia szybkość napełniania: $Q=900 \mathrm{~m}^{3} / \mathrm{h}$;

- temperatura paliwa: $t=+0,4^{\circ} \mathrm{C}$.

Za zbiornik ,pusty” uważano zbiornik, który w czasie operacji przeładunkowych został wypełniony paliwem do około $60 \%$ maksymalnego stopnia wypełnienia, przy czym próbki zostały pobrane w początkowym etapie napełniania zbiornika:

- numer zbiornika: 10.3;

- pojemność zbiornika: $V=10000 \mathrm{~m}^{3}$;

- średnica zbiornika: $29 \mathrm{~m}$;

- maksymalna wysokość paliwa w zbiorniku: 14 m;

- wysokość zbiornika do króćca pomiarowego: 15 m;

- napełnianie od około $3600 \mathrm{~m}^{3}$ (około 5,5 m) do około $5900 \mathrm{~m}^{3}$ (około $9 \mathrm{~m}$ );

- średnia szybkość napełniania: $Q=900 \mathrm{~m}^{3} / \mathrm{h}$;

- temperatura paliwa: $t=+1,6^{\circ} \mathrm{C}$.

W tabelach 5 i 6 zamieszczono wyniki analiz składu próbek pobranych do strzykawek gazoszczelnych dla danego zbiornika. W ostatnim wierszu tabel podano wyniki obliczeń stężenia węglowodorów w danej próbce, wyrażonego $\mathrm{w} \mathrm{mg} / \mathrm{m}^{3}$. Ponieważ podana w tabeli 5 zawartość węglowodorów jest stosunkowo duża, uzyskane wyniki pozwalają na względnie dobre oszacowanie przeciętnej masy molowej węglowodorów w fazie gazowej, podane w ostatnim wierszu tabeli.

\section{Analiza próbek gazowych tzw. matego oddechu}

Próbki gazowe dla tzw. małego oddechu zostały pobrane ze zbiorników magazynowych o numerach 10.4 i 16 (E1), o różnym stopniu wypełnienia paliwem ciekłym. W przypadku każdego zbiornika pobrano po cztery próbki gazowe w przedziale czasowym co 2 minuty. Poniżej zamieszczono dane dotyczące zbiorników i warunki poboru próbek.

Zbiornik ,,pełny”, tzn. zbiornik wypełniony paliwem do maksymalnego możliwego stopnia wypełnienia:

- $\quad$ numer zbiornika: 10.4;

- pojemność zbiornika: $V=10000 \mathrm{~m}^{3}$;

- średnica zbiornika: $29 \mathrm{~m}$;

- maksymalna wysokość paliwa w zbiorniku: 14000 mm;

- wysokość zbiornika do króćca pomiarowego: 15000 mm;

- napełnienie: $9400 \mathrm{~m}^{3}$ (14000 mm);

- temperatura paliwa: $t=+26,1^{\circ} \mathrm{C}$.

Zbiornik ,pusty”, tzn. zbiornik wypełniony paliwem do stopnia opisanego poniżej:

- numer zbiornika: 16 (E1); 
Tabela 5. Wyniki analizy próbek dla zbiornika 10.5 (zbiornik pełny)

Table 5. Sample analysis results for tank 10.5 (full tank)

\begin{tabular}{|c|c|c|c|c|c|}
\hline \multirow{2}{*}{ Nazwa składnika } & Próbka 1 & Próbka 2 & Próbka 3 & Próbka 4 & Próbka 5 \\
\hline & \multicolumn{5}{|c|}{ [\% obj.] } \\
\hline Propan & 0,0006 & 0,0005 & 0,0006 & 0,0007 & 0,0008 \\
\hline i-Butan & 0,0010 & 0,0010 & 0,0010 & 0,0020 & 0,0013 \\
\hline n-Butan & 0,0020 & 0,0010 & 0,0020 & 0,0020 & 0,0015 \\
\hline Pentany $\left(\mathrm{C}_{5} \mathrm{H}_{12}\right)$ & 0,0050 & 0,0010 & 0,0030 & 0,0040 & 0,0030 \\
\hline Heksany $\left(\mathrm{C}_{6} \mathrm{H}_{14}\right)$ & 0,0010 & 0,0010 & 0,0010 & 0,0010 & 0,0010 \\
\hline Węglowodory $\mathrm{C}_{7}$ & 0,0033 & 0,0028 & 0,0028 & 0,0030 & 0,0032 \\
\hline Węglowodory $\mathrm{C}_{8}$ & 0,0090 & 0,0072 & 0,0076 & 0,0088 & 0,0120 \\
\hline Węglowodory $\mathrm{C}_{9}-\mathrm{C}_{10}$ & 0,0230 & 0,0180 & 0,0210 & 0,0120 & 0,0120 \\
\hline Węglowodory $\mathrm{C}_{11}$ & 0,0001 & - & - & 0,0002 & 0,0002 \\
\hline Węglowodory $\mathrm{C}_{12}$ & 0,0007 & 0,0004 & 0,0007 & 0,0005 & 0,0004 \\
\hline Węglowodory $\mathrm{C}_{13}$ & 0,0011 & 0,0012 & 0,0008 & 0,0004 & 0,0003 \\
\hline Wyższe & 0,0001 & - & - & - & - \\
\hline$\sum$ węglowodorów & 0,0469 & 0,0341 & 0,0405 & 0,0346 & 0,0357 \\
\hline \multicolumn{6}{|c|}{$\left[\mathrm{mg} / \mathrm{m}^{3}\right]$} \\
\hline Stężenie $\sum$ węglowodorów & 2435 & 1841 & 2125 & 1677 & 1772 \\
\hline \multicolumn{6}{|c|}{$[\mathrm{kg} / \mathrm{kmol}]$} \\
\hline Przeciętna masa molowa & 119 & 124 & 120 & 110 & 113 \\
\hline
\end{tabular}

Uwagi:

Brak podanej wartości oznacza, że nie stwierdzono obecności węglowodorów w próbce - granica wykrywalności metody wynosiła $0,0001 \%$ obj.

Prężność par nasyconych w $T=0,4^{\circ} \mathrm{C}: 0,045 \mathrm{kPa}\left(2612 \mathrm{mg} / \mathrm{m}^{3}\right)$.

Średnie stężenie węglowodorów: $1970 \mathrm{mg} / \mathrm{m}^{3}$.

Stopień nasycenia: 0,75 .

Tabela 6. Wyniki analizy próbek dla zbiornika 10.3 (zbiornik pusty)

Table 6. Sample analysis results for tank 10.3 (empty tank)

\begin{tabular}{|c|c|c|c|c|c|}
\hline \multirow{2}{*}{ Nazwa skladnika } & Próbka 1 & Próbka 2 & Próbka 3 & Próbka 4 & Próbka 5 \\
\hline & \multicolumn{5}{|c|}{$[\%$ obj.] } \\
\hline Węglowodory $\mathrm{C}_{7}$ & 0,0010 & 0,0004 & 0,0012 & 0,0001 & 0,0008 \\
\hline Węglowodory $\mathrm{C}_{8}$ & 0,0014 & - & 0,0034 & - & 0,0025 \\
\hline Węglowodory $\mathrm{C}_{9}-\mathrm{C}_{10}$ & 0,0020 & 0,0002 & 0,0070 & 0,0009 & 0,0034 \\
\hline Węglowodory $\mathrm{C}_{11}$ & 0,0001 & - & - & - & - \\
\hline Węglowodory $\mathrm{C}_{12}$ & 0,0001 & - & 0,0001 & - & 0,0001 \\
\hline Węglowodory $\mathrm{C}_{13}$ & 0,0001 & - & - & - & - \\
\hline Wyższe & - & - & - & 0,0004 & 0,0002 \\
\hline \multirow[t]{2}{*}{$\sum$ węglowodorów } & 0,0047 & 0,0006 & 0,0117 & 0,0014 & 0,0070 \\
\hline & \multicolumn{5}{|c|}{$\left[\mathrm{mg} / \mathrm{m}^{3}\right]$} \\
\hline Stężenie $\sum$ węglowodorów & 260 & 30 & 657 & 59 & 376 \\
\hline
\end{tabular}

Uwagi:

1. Brak podanej wartości oznacza, że nie stwierdzono obecności węglowodorów w próbce - granica wykrywalności metody wynosiła $0,0001 \%$ obj.

2. W próbkach nie wykryto węglowodorów $\mathrm{C}_{3}-\mathrm{C}_{6}$.

3. Duże różnice stężeń węglowodorów w gazach z „dużego oddechu” przy pustym zbiorniku odzwierciedlają dynamikę procesu towarzyszącą parowaniu pozostałości paliw i związaną m.in. z nierównomiernym rozkładem stężeń węglowodorów w przestrzeni gazowej zbiornika, spowodowanym dużą objętością tej przestrzeni, zlokalizowaniem króćca oddechowego przy dolnej krawędzi kopuły dachu, zaciąganiem do wnętrza zbiornika powietrza atmosferycznego w czasie spadku temperatury (przed napełnianiem) i dużą różnicą gęstości par węglowodorów i powietrza. Uzyskane wartości mogą posłużyć do oszacowania przedziału zmienności obserwowanych wartości stężenia węglowodorów.

Prężność par nasyconych w $T=1,6^{\circ} \mathrm{C}: 0,048 \mathrm{kPa}\left(2786 \mathrm{mg} / \mathrm{m}^{3}\right)$.

Średnie stężenie węglowodorów: $276 \mathrm{mg} / \mathrm{m}^{3}$.

Stopień nasycenia: 0,1 . 
Tabela 7. Wyniki analizy próbek dla zbiornika 10.4 (zbiornik pełny)

Table 7. Sample analysis results for tank 10.4 (full tank)

\begin{tabular}{|c|c|c|c|c|}
\hline \multirow{2}{*}{ Nazwa składnika } & Próbka 1 & Próbka 2 & Próbka 3 & Próbka 4 \\
\hline & \multicolumn{4}{|c|}{ [\% obj.] } \\
\hline Propan & 0,0001 & - & - & - \\
\hline i-Butan & 0,0008 & - & - & - \\
\hline n-Butan & 0,0009 & - & - & - \\
\hline Pentany $\left(\mathrm{C}_{5} \mathrm{H}_{12}\right)$ & 0,0012 & - & - & - \\
\hline Heksany $\left(\mathrm{C}_{6} \mathrm{H}_{14}\right)$ & 0,0007 & - & - & - \\
\hline Węglowodory $\mathrm{C}_{7}$ & 0,0017 & 0,0002 & 0,0001 & 0,0001 \\
\hline Węglowodory $\mathrm{C}_{8}$ & 0,0073 & 0,0014 & 0,0007 & 0,0013 \\
\hline Węglowodory $\mathrm{C}_{9}-\mathrm{C}_{10}$ & 0,0180 & 0,0063 & 0,0062 & 0,0055 \\
\hline Węglowodory $\mathrm{C}_{11}$ & 0,0002 & 0,0004 & 0,0001 & 0,0002 \\
\hline Węglowodory $\mathrm{C}_{12}$ & 0,0006 & 0,0004 & 0,0001 & 0,0002 \\
\hline Węglowodory $\mathrm{C}_{13}$ & 0,0002 & 0,0002 & 0,0002 & 0,0002 \\
\hline Wyższe & 0,0005 & 0,0004 & 0,0008 & 0,0003 \\
\hline$\sum$ węglowodorów & 0,0322 & 0,0093 & 0,0082 & 0,0078 \\
\hline \multicolumn{5}{|c|}{$\left[\mathrm{mg} / \mathrm{m}^{3}\right]$} \\
\hline Stężenie $\sum$ węglowodorów & 1787 & 570 & 515 & 472 \\
\hline
\end{tabular}

Uwagi:

1. Brak podanej wartości oznacza, że nie stwierdzono obecności węglowodorów w próbce - granica wykrywalności metody wynosiła $0,0001 \%$ obj.

2. Odbiegające od pozostałych próbek zarówno skład, jak i stężenie węglowodorów dla próbki 1 z dużym prawdopodobieństwem wynikają z poboru próbki gazowej podczas pierwszego porannego zrzutu gazu ze zbiornika danego dnia, co związane jest z wyższym nasyceniem gazu węglowodorami, które nastąpiło przez noc.

Prężność par nasyconych w $T=26,1^{\circ} \mathrm{C}: 0,199 \mathrm{kPa}\left(11549 \mathrm{mg} / \mathrm{m}^{3}\right)$.

Średnie stężenie węglowodorów: $568 \mathrm{mg} / \mathrm{m}^{3}$.

Stopień nasycenia: 0,05 .

Tabela 8. Wyniki analizy próbek dla zbiornika 16 (zbiornik pusty)

Table 8. Sample analysis results for tank 16 (empty tank)

\begin{tabular}{|c|c|c|c|c|}
\hline \multirow{2}{*}{ Nazwa skladnika } & Próbka 1 & Próbka 2 & Próbka 3 & Próbka 4 \\
\hline & \multicolumn{4}{|c|}{ [\% obj.] } \\
\hline Węglowodory $\mathrm{C}_{9}-\mathrm{C}_{10}$ & 0,0007 & 0,0004 & 0,0005 & 0,0001 \\
\hline Węglowodory $\mathrm{C}_{11}$ & - & - & - & 0,0001 \\
\hline Węglowodory $\mathrm{C}_{12}$ & - & - & - & - \\
\hline Węglowodory $\mathrm{C}_{13}$ & 0,0001 & 0,0003 & 0,0001 & - \\
\hline Wyższe & 0,0001 & 0,0002 & 0,0001 & 0,0001 \\
\hline$\sum$ węglowodorów & 0,0009 & 0,0009 & 0,0007 & 0,0003 \\
\hline \multicolumn{5}{|c|}{$\left[\mathrm{mg} / \mathrm{m}^{3}\right]$} \\
\hline Stężenie węglowodorów & 59 & 66 & 47 & 21 \\
\hline
\end{tabular}

Uwagi:

1. Brak podanej wartości oznacza, że nie stwierdzono obecności węglowodorów w próbce - granica wykrywalności metody wynosiła $0,0001 \%$ obj.

2. W próbkach nie wykryto węglowodorów $\mathrm{C}_{3}-\mathrm{C}_{8}$.

3. Widoczne skoki stężenia w próbkach gazowych pobranych w czasie zrzutów z dużym prawdopodobieństwem stanowią konsekwencję następujących po sobie krótkotrwałych wdechów i wydechów gazów do i ze zbiornika, wynikających z małej objętości przestrzeni gazowej wrażliwej na zmiany temperatury.

Prężność par nasyconych w $T=26,0^{\circ} \mathrm{C}: 0,198 \mathrm{kPa}\left(11491 \mathrm{mg} / \mathrm{m}^{3}\right)$.

Średnie stężenie węglowodorów: $47 \mathrm{mg} / \mathrm{m}^{3}$.

Stopień nasycenia: 0,004 . 
- pojemność zbiornika: $V=750 \mathrm{~m}^{3}$;

- średnica zbiornika: $10 \mathrm{~m}$;

- maksymalna wysokość paliwa w zbiorniku: $9500 \mathrm{~mm}$;

- wysokość zbiornika do króćca pomiarowego: 11000 mm;

- napełnienie: $100 \mathrm{~m}^{3}(1300 \mathrm{~mm})$;

- temperatura paliwa: $t=+26,0^{\circ} \mathrm{C}$.

W tabelach 7 i 8 zamieszczono wyniki analiz składu próbek pobranych do strzykawek gazoszczelnych dla danego zbiornika. W ostatnim wierszu tabel podano wyniki obliczeń stężenia węglowodorów w danej próbce, wyrażonego $\mathrm{w} \mathrm{mg} / \mathrm{m}^{3}$.

\section{Zalecenia projektowe}

Poniższe założenia zostały określone na podstawie danych historycznych i pomiarów wykonanych przez Politechnikę Śląską dla warunków bazy paliw TanQuid Polska w Radzionkowie. Do wszystkich przeliczeń sumarycznych udziałów objętościowych par węglowodorów w fazie gazowej na zawartość węglowodorów w g/m³ należy przyjmować średnią masę molową wynoszącą $130 \mathrm{~kg} / \mathrm{kmol}$.

\section{Obliczenia dla „dü̇ego oddechu”}

„Duży oddech” następuje w czasie napełniania zbiornika i tylko z aktualnie napełnianego zbiornika.

a) Emisja maksymalna (w ciągu 1 godziny):

- objętość gazów zrzutowych: równa objętości podanego do zbiornika oleju;

- temperatura oleju: maksymalna w okresie letnim $\left(28^{\circ} \mathrm{C}\right)$;

- napełnienie zbiornika: zbliżone do maksymalnego;

- zawartość węglowodorów w gazach: wynikająca z prężności par w maksymalnej temperaturze i stopnia nasycenia;

- stopień nasycenia: zalecany 0,75.

b) Emisja średnia (w ciągu roku):

- objętość gazów zrzutowych: równa objętości podanego do zbiornika oleju;

- temperatura oleju: średnia roczna $\left(10^{\circ} \mathrm{C}\right)$;

- napełnienie zbiornika: średnie (60\%);

- zawartość węglowodorów w gazach: wynikająca z prężności par w średniej temperaturze i stopnia nasycenia;

- $\quad$ stopień nasycenia: zalecany 0,4 .

\section{Obliczenia dla „matego oddechu”}

„Mały oddech” następuje w czasie wzrostu temperatury, zwykle ze wszystkich zbiorników równocześnie.

a) Emisja maksymalna (w ciągu 1 godziny) - zbiornik magazynowy:

- objętość gazów zrzutowych: obliczona na podstawie równania stanu gazu doskonałego;
- napełnienie zbiornika: $100 \%$;

- objętość początkowa: objętość przestrzeni gazowej zbiornika;

- temperatura oleju: maksymalna w okresie letnim $\left(28^{\circ} \mathrm{C}\right)$;

- maksymalny przyrost temperatury przestrzeni gazowej w ciągu godziny: $2,5^{\circ} \mathrm{C}$;

- przyrost temperatury produktu w ciągu godziny: do pominięcia;

- zawartość węglowodorów w gazach: wynikająca z prężności par w maksymalnej temperaturze i stopnia nasycenia;

- stopień nasycenia: 0,4.

b) Emisja maksymalna (w ciągu 1 godziny) - zbiornik operacyjny:

- objętość gazów zrzutowych: obliczona na podstawie równania stanu gazu doskonałego;

- napełnienie zbiornika: 60\%;

- objętość początkowa: objętość przestrzeni gazowej zbiornika;

- temperatura oleju: maksymalna w okresie letnim $\left(28^{\circ} \mathrm{C}\right)$;

- maksymalny przyrost temperatury przestrzeni gazowej w ciągu godziny: $2,5^{\circ} \mathrm{C}$;

- przyrost temperatury produktu w ciągu godziny: do pominięcia;

- zawartość węglowodorów w gazach: wynikająca z prężności par w maksymalnej temperaturze i stopnia nasycenia;

- $\quad$ stopień nasycenia: 0,3.

c) Emisja średnia (w ciągu roku) - zbiornik magazynowy:

- obliczenie według AP-42 (EPA): zgodnie z algorytmem:

- warunki atmosferyczne: dobrać na podstawie analizy i porównania danych meteorologicznych miasta znajdującego się na terenie Stanów Zjednoczonych Ameryki o warunkach pogodowych podobnych do miejsca lokalizacji zbiorników,

- napełnienie zbiornika: 100\%,

- średnia temperatura powierzchni produktu w ciągu roku: według warunków lokalnych (dla TQ: $10^{\circ} \mathrm{C}$ ),

- prężność par dla średniej temperatury produktu: według danych AP-42,

- masa molowa: $130 \mathrm{~kg} / \mathrm{kmol}$;

- obliczenie według równania stanu gazu doskonałego:

- warunki atmosferyczne:

- liczba dni w roku, w których występuje oddech: 40-60\%, średnio 175 dni w roku,

- maksymalny dobowy przyrost temperatury w zbiorniku: $18^{\circ} \mathrm{C}$,

- Średni dobowy przyrost temperatury w zbiorniku: 60-70\% maksymalnego,

- objętość gazów zrzutowych (dobowa): wzrost temperatury + wzrost prężności par, 
- objętość gazów zrzutowych (roczna): maks. $\mathrm{m}^{3} /$ dobę $\times$ dni $/$ rok $\times 0,4$,

- średnia roczna temperatura oleju: według warunków lokalnych (dla TQ: $10^{\circ} \mathrm{C}$ ),

- napełnienie zbiornika: 100\%,

- zawartość węglowodorów w gazach: wynikająca z prężności w średniej temperaturze i stopnia nasycenia,

- stopień nasycenia: zalecany 0,4 .

d) Emisja średnia (w ciągu roku) - zbiornik operacyjny:

- obliczenie według AP-42: zgodnie z algorytmem:

- dane jak punkcie c;

- obliczenie według równania stanu gazu doskonałego:

- warunki atmosferyczne:

- liczba dni w roku, w których występuje oddech: $40-60 \%$,

- maksymalny dobowy przyrost temperatury w zbiorniku: $18^{\circ} \mathrm{C}$,

- Średni dobowy przyrost temperatury w zbiorniku: 60-70\% maksymalnego;

- objętość gazów zrzutowych (roczna):

maks. $\mathrm{m}^{3} /$ dobę $\times$ dni/rok $\times 0,3$;

- średnia roczna temperatura oleju: wg warunków lokalnych (dla TQ: $10^{\circ} \mathrm{C}$ );

- napełnienie zbiornika: 50-60\%;

- zawartość węglowodorów w gazach: wynikająca z prężności w średniej temperaturze i stopnia nasycenia;

- stopień nasycenia: 0,3.

\section{Zalecenia ogólne}

1. Przy określaniu zrzutów tzw. małego oddechu ze zbiornika, z którego jest wydawane paliwo, należy przyjąć, że zrzut ten jest znacząco niższy ze względu na zmniejszanie się objętości produktu w zbiorniku, a więc z powodu odpowiedniej kompensacji przyrostu objętości gazów.

2. Zalecenia projektowe podane w niniejszym opracowaniu zostały oparte na wynikach pomiarów wykonanych głównie dla zbiorników o pojemności $V=10000 \mathrm{~m}^{3}$. Temperatury sprawdzano również dla zbiorników o pojemnościach $V=750 \mathrm{~m}^{3}, V=2000 \mathrm{~m}^{3}, V=3000 \mathrm{~m}^{3}, V=6000 \mathrm{~m}^{3}$, $V=8000 \mathrm{~m}^{3}$ i $V=14000 \mathrm{~m}^{3}$, a ,mały oddech" na zbiorniku o pojemności $V=750 \mathrm{~m}^{3}$.

3. Zaleca się nie przyjmować dla żadnych warunków mniejszego stopnia nasycenia niż 0,1 .

4. Zaleca się przyjęcie do wszystkich wyników obliczeń współczynnika korygującego na poziomie 1,15.

\section{Wnioski}

\section{Prężność par nasyconych oleju napedowego}

Właściwości olejów napędowych, w tym prężność par nasyconych, nie są wielkościami stałymi i zależą od zawartości w nich poszczególnych węglowodorów i ich izomerów. Zebrane dane literaturowe oraz obliczeniowe uzyskane na podstawie przeprowadzonych badań wykazują znaczną rozbieżność wartości liczbowych dotyczących prężności par nasyconych dla oleju napędowego. Opracowana obliczeniowo krzywa prężności par oraz matematyczna funkcja opisująca tę krzywą pozwalają na oszacowanie prężności par oleju napędowego w zależności od temperatury z dokładnością wystarczającą do zastosowań projektowych. Wyniki obliczeń prężności par oleju napędowego w zależności od temperatury obliczone na podstawie równania Antoine'a i otrzymanych współczynników do równania są na poziomie zbliżonym do większości danych literaturowych oraz do wyników pomiarów prężności wykonanych przez Politechnikę Śląską we współpracy z bazą paliw TanQuid Polska.

\section{Średnia masa molowa par oleju napędowego}

Masa molowa par oleju napędowego obliczona na podstawie gęstości tych par podanych w kartach charakterystyki olejów wynosi powyżej $140 \mathrm{~kg} / \mathrm{kmol}$. Wartość ta nie została potwierdzona w przeprowadzonych badaniach - w tych przypadkach, gdy można to wiarygodnie ocenić (np. tabela 5), skład fazy gazowej wskazuje, że przeciętna masa molowa par węglowodorów mieści się w granicach od $110 \mathrm{~kg} / \mathrm{kmol}$ do $124 \mathrm{~kg} / \mathrm{kmol}$ - do obliczeń w niniejszej pracy przyjęto bezpiecznie $130 \mathrm{~kg} / \mathrm{kmol}$.

\section{„Duży oddech” i stężenia weglowodorów w gazach zrzutowych w czasie jego trwania}

Objętość gazów odprowadzanych do atmosfery w czasie „dużego oddechu” (napełniania zbiornika) jest równa objętości podanego do zbiornika oleju napędowego. Zgodnie z obliczeniami wykonanymi według AP-42 stężenia węglowodorów w gazach wypychanych ze zbiornika przy „dużym oddechu” są stałe, niezależne od napełnienia zbiornika. Założenie takie nie jest wiarygodne w świetle przeprowadzonych pomiarów, które jednoznacznie wskazują, że stężenie to w znacznym stopniu zależy od napełnienia zbiornika i waha się od wielkości zbliżonej do stężenia par nasyconych przy pełnym zbiorniku (stopień nasycenia do 0,7 ) do stężeń wielokrotnie niższych przy zbiorniku pustym (stopień nasycenia poniżej 0,1).

\section{„Maty oddech” i stężenia węglowodorów w gazach zrzutowych w czasie jego trwania}

Przytoczone dane literaturowe nie pozwalają na określenie objętości gazów odprowadzanych do atmosfery w czasie „,małego 
oddechu" (obliczenia wg AP-42 określają jedynie roczną ilość węglowodorów emitowaną do atmosfery) oraz stężeń węglowodorów w tych gazach. Przeprowadzone pomiary wskazują, że w czasie „małego oddechu” stężenia węglowodorów w gazach odprowadzanych do atmosfery są wielokrotnie niższe od stężeń równowagowych (stopień nasycenia nawet poniżej 0,05), przy czym występuje podobna zależność tych stężeń w zależności od stopnia napełnienia zbiornika jak w czasie „dużego oddechu”.

\section{Emisja maksymalna godzinowa (emisja uśredniona dla jednej godziny)}

Maksymalną emisję godzinową stanowi suma zrzutów z ,małego oddechu” ze wszystkich zbiorników oleju napędowego i zrzutu z ,dużego oddechu” z aktualnie napełnianego zbiornika. Zrzuty z ,dużego oddechu” są równe objętości wtłoczonego do zbiornika w ciągu godziny oleju napędowego, przy stężeniach węglowodorów w warunkach ekstremalnych (uwzględniając stopień nasycenia), przyjętych na podstawie przeprowadzonych pomiarów. Nie znaleziono w dostępnych materiałach danych pozwalających na oszacowanie maksymalnych zrzutów w ciągu godziny z „małego oddechu”. Zrzuty te są możliwe do określenia jedynie na podstawie równania stanu gazu doskonałego oraz zmierzonych stężeń węglowodorów występujących w tym zrzucie.

\section{Emisja (straty) roczna (średnia emisja dla okresu obliczeniowego - jednego roku)}

Obliczenia rocznej emisji (strat) węglowodorów według AP-42 (EPA) oraz na podstawie równania stanu gazu doskonałego, przy przyjęciu do obliczeń identycznych danych, dają zbliżone wyniki. Decydującymi wielkościami i czynnikami dla tych obliczeń są średnia roczna temperatura magazynowanego oleju napędowego, prężność par nasyconych oleju napędowego w tej temperaturze oraz warunki atmosferyczne.

Artykuł powstał na podstawie badań zrealizowanych przez Politechnikę Śląską w Gliwicach zleconych przez TanQuid Polska Sp. z o.o.

\section{Literatura}

Apex Oil Company, 2015. No. 2 Fuel Oil Safety Data Sheet, Revision date $03 / 06 / 2015$

Chevron Philips Chemical Company LP, 2017. Diesel Fuel T-30 Safety Data Sheet, Version 1.14, Revision date 16/05/2017.

CITGO, 2018. No. 2 Fuel, Diesel Safety Data Sheet, Version 1, Revision date 22/03/2018.

Klimat Radzionków, 2019. <https:/www.meteoblue.com/pl/pogo$\mathrm{da} /$ historyclimate/climatemodelled/radzionk\%c3\%b3w_polska_3087418> (dostęp: 09.09.2019).

Konieczyński J., 1993. Oczyszczanie gazów odlotowych. Wydawnictwo Politechniki Ślaskiej, Gliwice.

Lotos, 2018. Karta charakterystyki oleju napędowego nr 2, wydanie nr 11, wersja 1 z dnia 03/09/2018.
Naftan, 2018. Karta charakterystyki oleju napędowego, wersja 2, aktualizacja z dnia 18/03/2018.

Shell Trading Rotterdam B.V., 2018. No. 2 Fuel, Diesel Safety Data Sheet, Version 1.1, Effective Date 01/08/2018.

Slovnaft, 2018. Karta charakterystyki oleju napędowego, wersja 18 , wydana w dniu 14/06/2018.

TanQuid, 2019. Pomiary własne.

Total, 2018. Karta charakterystyki oleju napędowego, wersja 3, wydana w dniu 02/01/2018.

Vitol, 2015. Fuel Oil No. 2 Safety Data Sheet, Revision 003, Revision date $09 / 2015$.

Yaws C.L., Narasimhan P.K., Gabbula Ch., 2009. Yaws' Handbook of Antoine Coefficients for Vapor Pressure ( $2^{\text {nd }}$ Electronic Edition). Knovel.

\section{Akty normatywne i prawne}

EN ISO/IEC 17025 Ogólne wymagania dotyczące kompetencji laboratoriów badawczych i wzorcujacych.

EPA, United States Environmental Protection Agency. AP-42: Compilation of Air Emissions Factors, Fifth Edition.

PN-EN 13649:2005 Emisja ze źródeł stacjonarnych - Oznaczanie stężenia masowego indywidualnych gazowych związków organicznych - Metoda z zastosowaniem węgla aktywnego i desorpcji rozpuszczalnikiem.

PN-EN 590+A1:2017-06 Paliwa do pojazdów samochodowych Oleje napędowe - Wymagania i metody badań.

Rozporządzenie Ministra Gospodarki z dnia 21 listopada 2005 r. (Dz.U. Nr 243, poz. 2063 z późn. zm.).

Rozporządzenie Ministra Środowiska z dnia 26 stycznia 2010 r. (Dz.U. Nr 16, poz. 87).

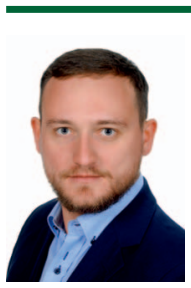

Mgr inż. Jakub DOMIN

Koordynator ds. projektów Tanquid Polska Sp. z o.o. ul. Zofii Nałkowskiej 51

41-922 Radzionków

E-mail:jakubdomin@gmail.com

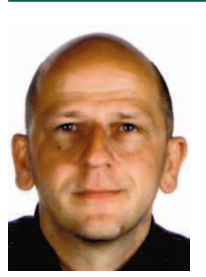

Mgr inż. Marek PIECHOTA

Specjalista ds. biopaliw w Tanquid Polska Sp. z o.o. ul. Zofii Nałkowskiej 51

41-922 Radzionków

E-mail:marek.piechota@tanquid.com

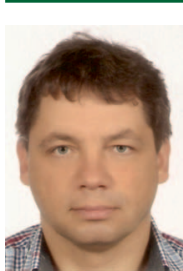

Dr inż. Dymitr CZECHOWICZ

Adiunkt w Katedrze Technologii Chemicznej

Organicznej i Petrochemii

Wydział Chemiczny Politechniki Śląskiej

ul. Bolesława Krzywoustego 4

44-100 Gliwice.

E-mail: dymitr.czechowicz@polsl.pl

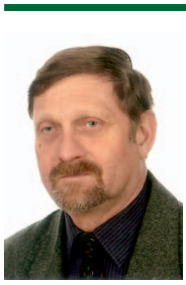

Dr inż. Krzysztof SKUTIL

Starszy wykładowca w Katedrze Technologii

Chemicznej Organicznej i Petrochemii

Wydział Chemiczny Politechniki Śląskiej

ul. Bolesława Krzywoustego 4

44-100 Gliwice

E-mail:krzysztof.skutil@polsl.pl 